\title{
Analysis and Evaluation Service Quality with Fuzzy - Banking Service Quality in East Java, Indonesia
}

\author{
Rachmad Hidayat ${ }^{1}$ \\ Department of Industrial Engineering \\ University of Trunojoyo Madura \\ Bangkalan, Indonesia \\ ${ }^{1}$ rachmad.hidayat@trunojoyo.ac.id
}

\author{
Harliwanti Prisilia ${ }^{2}$ \\ Department of Industrial Engineering \\ University of 17 Agustus 1945 \\ Banyuwangi, Indonesia \\ ²harliwantip@yahoo.com
}

\begin{abstract}
The research aimed ad analyzing and evaluating the banking service quality in East Java. The research to know the service standard which is suitable for the customer's desire and arranges an improvement priority of service quality that should be given to the customers. The method used to measure quality is Fuzzy Banking Service Quality. Service quality analysis by using fuzzy Banking Service Quality which is aided by using the MATLAB application. Based on the research results, customers valuation average toward the bank customer level is good. The services given have fulfilled the customer expectation. There is service which becomes the priority to be improved that is e-chanel, e-Banking, sms banking and ATM, competitive interest and parking lot for customers.
\end{abstract}

Keywords-fuzzy-banking service quality; e-channel; ebanking; sms banking

\section{INTRODUCTION}

Banking is service based on trust and gives emphasis to the service quality [1]. The service quality is an important factor in determining the success of banking [2]. The phenomenon occurred in almost all banks, the customers need maximum services continuously. Service quality gives encourage to the customers, to make a strong bond with the bank [3]. In long term make possible the bank to understand the customer's satisfaction and customers needs. Bank able to improve the customer's satisfaction by maximizing the please customers experience, and minimizing less please experiences. Service quality becomes the expected advantage level and control for the advantage to fulfill the consumer's needs [4]. Service quality becomes the main component for the bank products. The competition will be influenced by the bank ability to give best services compared to the competitor [5]. The dimension of service quality is the picture for the how far the differences between perceived service, with expected service for the services received by the customers. The discrepancy between perceived service to expected services creates service quality problem called GAP [6].

Service quality measurement usually used to measure the quality of a conventional bank and the mostly used is
SERVQUAL. SERVQUAL based on "Gap Model” developed by Parasuraman, et al. [7]. SERVQUAL based on five quality dimensions, tangibles, reliability, responsiveness, assurance, and empathy [8]. Service quality becomes worse caused by (a). not skilled in servicing consumers $b$. the dress does not fit $c$. impolite speech or cause resentment d. disturbing body odor e. always sullen [9]. Factors that should be considered in improving the service quality is a. identifying the main determinant of service quality and estimate the given valuation by the target market $b$. manage the customer's expectation by promising the services can be promised c. strengthen the customer's perception during and after services given $d$. develop a quality culture that produces conductive environment and quality perfection continuously [10]. Quality culture consists of philosophy, belief, attitude, norm, value, tradition, procedure, and expectation [11].

Development of then the banking service quality concept is Banking Service Quality (BSQ) [12]. BSQ has higher validity and reliability level compared to SERVQUAL. [13]. BSQ consists of six dimensions: (1) Effectiveness and Assurance is combination of competence and good response level from employee and security factor (2) Access is customers perception toward modern equipment and important element that guarantee the easy access for transaction (3) Price is factor that relates directly to the cost charged (4) Tangible refer to atmosphere, service equipment, and service appearance. (5) Service Portfolio, refer to complete service and consistent service follow the banking world development 6 . Reliability is formed from two indicators, that is good archiving and no mistake in process of service delivery [12]

The research aimed at analyzing and evaluating the banking service quality in East Java. The research can be used as consideration to improve the service quality in East Java. Banking service quality is any services delivery maximum given by the bank. Service quality is a statement about attitude, and relationship produced from the comparison between expectation and performance. The research focus on banking service, that is BSQ and Fuzzy method. The fuzzy method is used to prevent uncertain individual viewpoint toward perception and expectation desired [14]. Fuzzy - Banking Service Quality is a fuzzy set theory which gives means to 
represent uncertainty and a tool for modeling the uncertainty that relates with the fuzziness, uncertainty and lack of information about a certain element from the problem faced [15].

\section{METHOD}

The research was done at one of the banks in East Java. The research is also survey research, which is part of descriptive research, research done to obtain facts from the existing symptoms and find a factual explanation to get the truth. Data collected from the population by using questionnaires as the data collecting tools. The population of the research is the Mandiri Bank customers of East Java of 6155 customers. A sample of the research was determined by a slovin formula of 99 persons [16]. The instrument used in the research is a questionnaire. Open questionnaires were used to know the customer's desires about banking services. Then will become variable in the research. While closed questionnaires, to know the characteristic interest and the attribute category of the customer services.

Variables which are measured come from Banking Service Quality (BSQ). From the recapitulation of open questionnaires were obtained the attributes of consumers desires. The attributes are the questions in the closed questionnaire to categorize the attributes become closed questionnaires questions to categorize the attributes that become the questionnaires questions items such as (1) regulation easy to understand (2) the requirements not complicated (3) carefulness, efficiency, and service speed (4) guarantee under government umbrella, (5) the presence of E-channel, EBanking, sms Banking and ATM, (6) the presence of comfort
Banking Hall, (7) the park lot availability, (8) administrative easiness, (9) competitive interest, (10) loan with low interest. One dimensional category gives the concept that satisfaction linearly connected with the given performance [17]. While for an attribute with the attractive category is the customers need that not depend on the category given by the attribute.

Validity test is done to know the distributed questionnaire accuracy [18]. Attribute is valid if rcalculaton >rtable, while data considered as reliable if the Cronbach Alpha > 0,6 [19]. At the recapitulation stage, the data processing and analysis, the researcher recapitulate the obtained data from questionnaires, determine the scoring average of perception and expectation, calculate gap, then calculate the BSQ score by calculating the gap average among criteria. Then at the analysis stage, the technique done by using fuzzy logic concept through MATLAB program. Then, implementation and analysis of Fuzzy BSQ with rules arranged by using Matlab Fuzzy Logic ToolBox to know the services quality of Mandiri Bank in East Java.

\section{DISCUSSION}

\section{A. Banking Service Quality (BSQ)}

Based on gaps models of service quality [20], from gap which gave impact to service quality, the gap between the customer's perception and expectation about service quality. If the customer's perception and expectation proved equal and even the perception better then expectation then the bank gets a positive image and impact if the otherwise then will cause problems for the bank [21]. By using data processing at BSQ method, the calculation obtained given in Table 1 .

TABLE I. CALCULATION OF BSQ AND GAP

\begin{tabular}{|c|c|c|c|c|}
\hline \multirow{2}{*}{ Number } & \multirow[t]{2}{*}{ Attributes of BSQ } & \multicolumn{2}{|c|}{ Average Attribute of BSQ } & \multirow[t]{2}{*}{ Gap of BSQ } \\
\hline & & Perception & Expectation & \\
\hline 1. & Regulation easy to understand & 4 & 4 & 0 \\
\hline 2. & Requirements not complicated & 4 & 4 & 0 \\
\hline 3. & Carefulness, efficiency and service speed & 4 & 4 & 0 \\
\hline 4. & Guarantee under government umbrella & 4 & 4.5 & -0.5 \\
\hline 5. & Presence of E-chanel, E-Banking, sms Banking and ATM services & 4 & 5 & -1 \\
\hline 6. & Presence of comfort Banking Hall & 4 & 4.25 & -0.25 \\
\hline 7. & Availability of parking lot & 4 & 4.67 & -0.67 \\
\hline 8. & Administrative easiness & 5 & 5 & 0 \\
\hline 9. & Competitive interest & 4.25 & 5 & -0.75 \\
\hline 10. & Loan with low interest & 4 & 4.5 & -0.5 \\
\hline \multicolumn{2}{|r|}{ Total } & 37.25 & 40.92 & -3.67 \\
\hline \multicolumn{2}{|r|}{ Average } & 3.725 & 4.092 & -0.367 \\
\hline
\end{tabular}

Based on Table 1. Stated that calculation of BSQ and gap, can be seen that the biggest gap is attribute "the presence of Echanel, E-Banking, sms Banking and ATM services" that is -1, means the attribute which according to the customers of Mandiri Bank in East Java, unable to fulfill the service quality which is suitable with customers expectation.

\section{1) Fuzzy Analysis}

Fuzzy logic is a decision making process based on rules aimed at problem solving. The system difficult to be modeled or there are ambiguity and vagueness. Many benefits of using fuzzy logic. Fuzzy logic conceptually easy to understand and has a natural approach. [22]. Steps done at the stages, that is fuzzification, inference, and defuzzyfication. At the step of langkah fuzzification, there are two input variables, perception and expectation and output variable that is service quality [23]. At input variable, that is perception and expectation given score with 5 parameters that are very important (VI)/ Very Satisfied (VS), Important (I) / Satisfied (S), Important Enough (IE)/ Satisfied Enough (SE), Not Important (NI)/ Not Satisfied (NS), Very Not Important (VNI)/ Very Not Satisfied (STP). While fuzzy interference produces an output of service quality, given score 3 (three) parameter, High $(\mathrm{H})$, Fair $(\mathrm{F})$ and Low (L). 
At the inference level, the determination of fuzzy logic rule is determined, the rule made to state the direct relationship between input and output suitable with the obtained data. An operator which is used to relate between two input is AND and which relate between input-output is IF-THEN. Based on the existing data, can be formed 25 rules, as follows:

1. If (Expectation is VNI) and (Perception is VNI) then (Service is R);

2. If (Expectation is NI) and (Perception is I) then (Service is F);

3. If (Expectation is IE) and (Perception is VNI) then (Service is R);

4. If (Expectation is IE) and (Perception is I) then (Service is F);

5. If (Expectation is VI) and (Perception is VI) then (Service is $\mathrm{H}$ )

6. If (Expectation is NI) and (Perception is IE) then (Service is $\mathrm{R}$ );

7. If (Expectation is IE) and (Perception is NI) then (Service is F);

The last step is (defuzzyfication), with the input of fuzzy set obtained from the fuzzy rule determined before and output produced is number in the fuzzy set itself. So, if given a fuzzy set in a certain range then can be taken the real value as output. The confirmation was done with aid of MATLAB ToolBox Fuzzy. Based on the data, expectation, and perception obtained, the measurement results of the service quality level of Mandiri Bank in East Java used the Fuzzy method, produced values as given in Table 2.

TABLE II. FUZZY SET

\begin{tabular}{|c|c|c|c|}
\hline $\begin{array}{c}\text { Range } \\
\text { analysis }\end{array}$ & $\begin{array}{c}\text { The name of the } \\
\text { Fuzzy Set }\end{array}$ & Domain & Range \\
\hline $0-100$ & Very impotant & [65-100] & 6580100100 \\
\hline $0-100$ & Important & {$[50-80]$} & $50 \quad 6580$ \\
\hline $0-100$ & Important Enough & [35-65] & $35 \quad 50 \quad 65$ \\
\hline $0-100$ & Not Important & [20-50] & $2035 \quad 50$ \\
\hline $0-100$ & Not Importan & {$[0-35]$} & $\begin{array}{llll}0 & 0 & 20 & 35\end{array}$ \\
\hline
\end{tabular}

Membership function diagram for expectation variable as shown in Fig. 1.

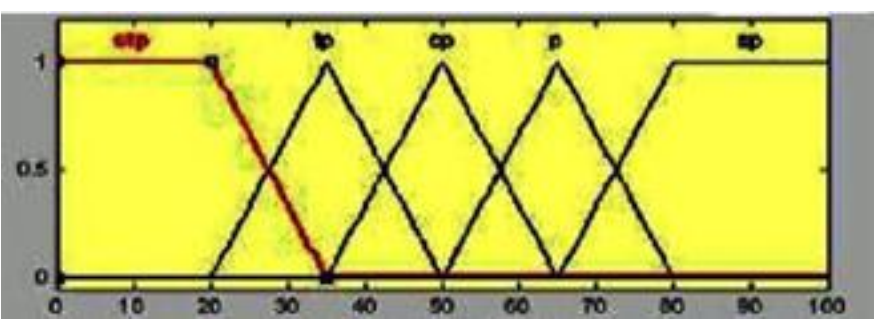

Fig. 1. Membership function diagram for expectation variable

At expectation variable in Table 2, data divided into 5 fuzzy sets, very not important, not important, important enough, important, and very important. The not important fuzzy set has domain [0-35] with the highest membership degree of 1 located at the value of 20 . The not important fuzzy set has domain [20-50] with the highest membership degree of
1 located at the value of 35 . Important enough fuzzy set has domain [35-65] with the highest membership degree of 1 located at the value of 50 . The important fuzzy set has domain [50-80] with the highest membership degree of 1 located at the value of 65. The very important fuzzy set has domain [65-100] with the highest membership degree of 1 located at the value of 80. If the expectation variable value more than 20 , then the value closer to not important. The membership function formation for the fuzzy set, that is very not important and not important, as follows.

Membership function for the very not important set can be seen in equation (1).

$$
\mu S T P_{\left[X_{i}\right]}= \begin{cases}0 ; & X_{i} \geq 35 \\ \frac{\left(35-X_{i}\right)}{35-20} ; & 20 \leq X_{i} \leq 35 \\ 1 ; & X_{i} \leq 20\end{cases}
$$

Membership function for the not important set can be seen in equation (2).

$$
\mu T P_{\left[X_{i}\right]}= \begin{cases}X_{i} \leq 20 \operatorname{atau}_{i} \geq 50 \\ \frac{\left(X_{i}-20\right)}{(35-20)} ; & 20 \leq X_{i} \leq 35 \\ \frac{\left(50-X_{i}\right)}{(50-35)} ; & 35 \leq X_{i} \leq 50\end{cases}
$$

At the perception variable, data divided into 5 fuzzy sets, very not satisfied, not satisfied, satisfied enough, satisfies, and very satisfied, with equal representation with the expectation variable. At the service variable, output variable with three tier valuation, low, fair, and high. Variable valuation is obtained from the calculation toward two variable input, that is expectation and perception.

\begin{tabular}{|c|c|c|c|}
\hline $\begin{array}{c}\text { Range } \\
\text { analysis }\end{array}$ & $\begin{array}{c}\text { The name of the } \\
\text { Fuzzy Set }\end{array}$ & Domain & Range \\
\hline $0-100$ & High & [50-100] & 6580100100 \\
\hline $0-100$ & Fair & [20-80] & 205080 \\
\hline $0-100$ & Low & {$[0-50]$} & $\begin{array}{lllll}0 & 0 & 20 & 50\end{array}$ \\
\hline
\end{tabular}

TABLE III. FuZZY SET VARIABLE SERVICE

Membership function diagram for variable service as shown in Fig. 2.

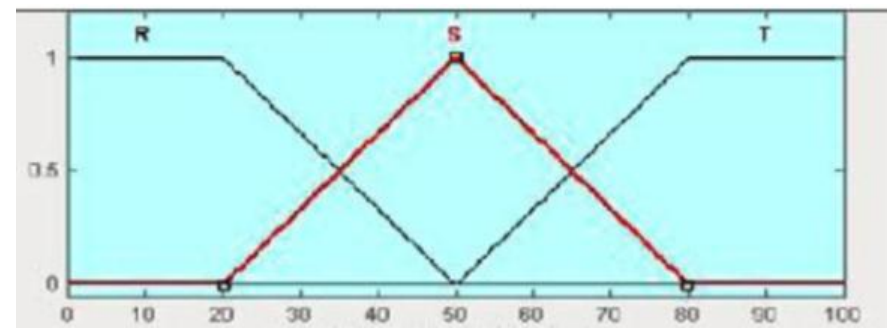

Fig. 2. Membership function diagram for expectation variable 
B. Processing of Servqual Fuzzy with Fuzzy Logic ToolBox

Based on data of expectation and perception obtained, from the service quality level measurement of Mandiri Bank in East
Java used the Fuzzy method of BSQ, produced values given in Table 4.

TABLE IV. MEASUREMENT RESULTS OF SERVICE QUALITY LEVEL

\begin{tabular}{|c|c|c|c|c|c|c|c|c|c|c|c|}
\hline \multirow{2}{*}{ Respondents } & \multicolumn{2}{|c|}{ Average score } & \multirow{2}{*}{ Gap } & \multirow{2}{*}{ Respondents } & \multicolumn{2}{|c|}{ Average score } & \multirow{2}{*}{ Gap } & \multirow{2}{*}{ Respondents } & \multicolumn{2}{|c|}{ Average score } & \multirow{2}{*}{ Gap } \\
\hline & Perc. & Exp. & & & Perc. & Exp. & & & Perc. & Exp. & \\
\hline 1. & 88 & 90 & 88.7 & 34. & 81.3 & 91.3 & 82.7 & 67. & 87 & 94 & 84 \\
\hline 2. & 65.4 & 85.4 & 81.6 & 35. & 74.7 & 87.8 & 79.4 & 68. & 65.4 & 85.4 & 81.6 \\
\hline 3. & 77.6 & 93.6 & 80.9 & 36. & 70.4 & 94.8 & 81.7 & 69. & 75.4 & 85.4 & 84.6 \\
\hline 4. & 75.4 & 85.4 & 84.6 & 37. & 73.6 & 92.6 & 84.8 & 70. & 81.8 & 91.2 & 83.2 \\
\hline 5. & 81.8 & 91.2 & 83.2 & 38. & 84.7 & 92.4 & 85.7 & 71. & 84.2 & 92.2 & 83.4 \\
\hline 6. & 84.2 & 92.2 & 83.4 & 39. & 90.4 & 95.4 & 92 & 72. & 74.7 & 94.7 & 89.7 \\
\hline 7. & 74.7 & 94.7 & 89.7 & 40. & 87 & 94 & 84 & 73. & 88.2 & 90 & 88.8 \\
\hline 8. & 88.2 & 90 & 88.8 & 41. & 65.4 & 85.4 & 81.6 & 74. & 87.6 & 97.6 & 94.5 \\
\hline 9. & 87.6 & 97.6 & 94.5 & 42. & 74.7 & 87.8 & 79.4 & 75. & 85.3 & 95.4 & 87.6 \\
\hline 10. & 85.3 & 95.4 & 87.6 & 43. & 70.4 & 94.8 & 81.7 & 76. & 74.7 & 87.8 & 79.4 \\
\hline 11. & 74.7 & 87.8 & 79.4 & 44. & 73.6 & 92.6 & 84.8 & 77. & 70.4 & 94.8 & 81.7 \\
\hline 12. & 70.4 & 94.8 & 81.7 & 45. & 84.7 & 92.4 & 85.7 & 78. & 73.6 & 92.6 & 84.8 \\
\hline 13. & 73.6 & 92.6 & 84.8 & 46. & 90.4 & 95.4 & 92 & 79. & 84.7 & 92.4 & 85.7 \\
\hline 14. & 84.7 & 92.4 & 85.7 & 47. & 87 & 94 & 84 & 80. & 90.4 & 95.4 & 92 \\
\hline 15. & 90.4 & 95.4 & 92 & 48. & 76.7 & 96.3 & 82.8 & 81. & 87 & 94 & 84 \\
\hline 16. & 87 & 94 & 84 & 49. & 74.7 & 94.7 & 89.7 & 82. & 90.4 & 95.4 & 92 \\
\hline 17. & 76.7 & 96.3 & 82.8 & 50. & 88.2 & 90 & 88.8 & 83. & 87 & 94 & 84 \\
\hline 18. & 80.2 & 94.7 & 85.4 & 51. & 87.6 & 97.6 & 94.5 & 84. & 65.4 & 85.4 & 81.6 \\
\hline 19. & 81.3 & 91.3 & 82.7 & 52. & 85.3 & 95.4 & 87.6 & 85. & 74.7 & 87.8 & 79.4 \\
\hline 20. & 74.7 & 87.8 & 79.4 & 53. & 74.7 & 87.8 & 79.4 & 86. & 70.4 & 94.8 & 81.7 \\
\hline 21. & 70.4 & 94.8 & 81.7 & 54. & 70.4 & 94.8 & 81.7 & 87. & 73.6 & 92.6 & 84.8 \\
\hline 22. & 73.6 & 92.6 & 84.8 & 55. & 73.6 & 92.6 & 84.8 & 88. & 84.7 & 92.4 & 85.7 \\
\hline 23. & 84.7 & 92.4 & 85.7 & 56. & 84.7 & 92.4 & 85.7 & 89. & 90.4 & 95.4 & 92 \\
\hline 24. & 90.4 & 95.4 & 92 & 57. & 90.4 & 95.4 & 92 & 90. & 87 & 94 & 84 \\
\hline 25. & 87 & 94 & 84 & 58. & 87 & 94 & 84 & 91. & 76.7 & 96.3 & 82.8 \\
\hline 26. & 65.4 & 85.4 & 81.6 & 59. & 76.7 & 96.3 & 82.8 & 92. & 74.7 & 94.7 & 89.7 \\
\hline 27. & 77.6 & 93.6 & 80.9 & 60. & 80.2 & 94.7 & 85.4 & 93. & 88.2 & 90 & 88.8 \\
\hline 28. & 76.4 & 94.3 & 80.4 & 61. & 81.3 & 91.3 & 82.7 & 94. & 87.6 & 97.6 & 94.5 \\
\hline 29. & 90.4 & 95.4 & 92 & 62. & 74.7 & 87.8 & 79.4 & 95. & 85.3 & 95.4 & 87.6 \\
\hline 30. & 87 & 94 & 84 & 63. & 70.4 & 94.8 & 81.7 & 96. & 76.7 & 96.3 & 82.8 \\
\hline 31. & 65.4 & 85.4 & 81.6 & 64. & 73.6 & 92.6 & 84.8 & 97. & 74.7 & 94.7 & 89.7 \\
\hline 32. & 77.6 & 93.6 & 80.9 & 65. & 84.7 & 92.4 & 85.7 & 98. & 88.2 & 90 & 88.8 \\
\hline 33. & 76.4 & 94.3 & 80.4 & 66. & 90.4 & 95.4 & 92 & 99. & 87.6 & 97.6 & 94.5 \\
\hline \multicolumn{9}{|c|}{ Average } & 80.12 & 92.75 & 85.31 \\
\hline
\end{tabular}

East Java so far can be considered as good. It is shown by an average score of BSQ values obtained showed a number of 95.31 from the range [0-100]. But from the data also obtained information that there is service attributes that not fulfill the expectation of Mandiri Bank customers in East Java. It means, there is should be efforts to improve the serving quality for Mandiri Bank customers in East Java so able to fulfill the desires and expectation of the societies. One thing that must be improved in case of e-chanel, e-Banking, sms banking and ATM, competitive interest and availability of parking lot.

\section{CONCLUSION}

Service quality of banking in East Java entirely is considered as good by the customers. It means the services given by bank has fulfilled the expectation of the customers. But from the BSQ gap analysis, it was known that there were 6 variables with negative gap values, expectation average value of customers more than the service perception. The variables are (1) guarantee under the government umbrella (2) presence of E-chanel, E-Banking, sms Banking and ATM services, (3) presence of comfort Banking Hall, (4) availability of parking lot (5) competitive interest (6) loan with low interest. Beside that also there are three priority variables that should be improved by banking in East Java that is, E-chanel, E-Banking, sms Banking and ATM, availability of parking lot and competitive interest.

\section{ACKNOWLEDGMENT}

This work was supported by the Grant of international publication on DIPA 2018 - University of Trunojoyo Madura. (SP DIPA-042.01.2.401029/2018).

\section{REFERENCES}

[1] C. Chen, "Perceived risk, usage frequency of mobile banking services. Managing Service Quality," An Int. J., vol. 23, pp. 410-436, 2013.

[2] M.M. Lau, et al., "Measuring service quality in the banking industry: a Hong Kong based study," Contemp. Manag. Res., vol. 9, 2013.

[3] J. Teixeira, et al., "Customer experience modeling: from customer experience to service design,” J. Serv. Manag., vol. 23(3), pp. 362-376, 2012.

[4] R. Hidayat and S. Akhmad, "The influence of service quality, religious commitment and trust on the customers' satisfaction and loyalty and 
decision to do the transaction in Mandiri Sharia bank of Jawa Timur," Al-Ulum, vol. 15(1), pp. 57-90, 2017.

[5] M. Mittal, S. Agrawal, and R. Gupta, "Study of Service Quality, Customer Satisfaction \& Customer Loyalty of Banks in India," Int. J. Banking, Risk and Insurance, vol. 4(2), pp. 59, 2016.

[6] N. Ray, "Expectation and Perception of Internet Banking Service Quality of Select Indian Private and Public Sector Banks: A Comparative Case Study," in Online Banking Security Measures and Data Protection, IGI Global, pp. 58-68, 2017.

[7] A. Parasuraman, L.L. Berry, and V.A. Zeithaml, "Refinement and reassessment of the SERVQUAL scale," J. retailing, vol. 67(4), pp. 420, 1991.

[8] A. Parasuraman, V. Zeithaml, and L. Berry, "SERVQUAL: a multipleitem scale for measuring consum. perceptions of service quality," Retailing: critical concepts, vol. 64(1), pp. 140, 2002.

[9] J.A. Martínez and L. Martinez, "Some insights on conceptualizing and measuring service quality," J. Retailing and Consum. Serv., vol. 17(1), pp. 29-42, 2010

[10] A. Parasuraman, V.A. Zeithaml, and A. Malhotra, "ES-QUAL: A multiple-item scale for assessing electronic service quality," J. Serv. Res., vol. 7(3), pp. 213-233, 2005.

[11] C. Basfirinci and A. Mitra, "A cross cultural investigation of airlines service quality through integration of Servqual and the Kano model," J. Air Transp. Manag., vol. 42, pp. 239-248, 2015.

[12] F. Abdullah, et al., "Bank service quality (BSQ) index: an indicator of service performance," Int. J. Qual. and Reliab. Manag., vol. 28(5), pp. 542-555, 2011.
[13] F. Abdullah, et al., "Managing Service Quality with BSQ Index", unpublished.

[14] H.T. Lin, "Fuzzy application in service quality analysis: An empirical study," Exp. Syst. with Appl., vol. 37(1), pp. 517-526, 2010.

[15] S.S. Ardakani, et al., "A fuzzy approach to service quality diagnosis," Marketing Intell. and Planning, vol. 33(1), pp. 103-119, 2015.

[16] J.J. Tejada and J.R.B. Punzalan, "On the misuse of Slovin's formula The Philippine Statistician,” vol. 61(1), pp. 129-136, 2012.

[17] K.C. Tan and T.A. Pawitra, "Integrating SERVQUAL and Kano's model into QFD for service excellence development," Manag. Serv. Quality: An Int. J., vol. 11(6), pp. 418-430, 2001.

[18] T. Kitagawa, "A test for instrument validity," Econometrica, vol. 83(5), pp. 2043-2063, 2015.

[19] L. Cohen, L. Manion, and K. Morrison, "Validity and reliability, in Research methods in education," Routledge. pp. 203-240, 2013.

[20] A. Shahin and M. Samea, "Developing the models of service quality gaps: a critical discussion,” Bus. Manag. and Strateg., vol. 1(1), pp. 2, 2010 .

[21] K. Bahia and J. Nantel, "A reliable and valid measurement scale for the perceived service quality of banks," Int. J. Bank Market., vol. 18(2), pp. 84-91, 2000.

[22] N. Baliyan and S. Kumar, "Quality assessment of software as a service on cloud using fuzzy logic" in Cloud Computing in Emerging Markets (CCEM), 2013 IEEE International Conference, 2013.

[23] Y.C. Hu and P.C. Liao, "Finding critical criteria of evaluating electronic service quality of Internet banking using fuzzy multiple-criteria decision making," Appl. Soft Comput., vol. 11(4), pp. 3764-3770, 2011. 